\title{
Recent Trends in Studies on the History of Geographical Thought in Japan - Mainly on the History of Japanese Geographical Thought -
}

\author{
Keiichi TAKEUCHI* and Hideki NozaWA **
}

\begin{abstract}
In this paper, the authors examine the recent state of the studies in the history of Japanese geographical thought, both traditional and modern. They remark that the increased interest in the history of geographical thought in recent decades in Japan is the reflection of the increasing concern over the epistemological and methodological interest in Japanese geography. The examinations conducted in this paper are also made in the context of methodological and epistemological reflections with regard to the intellectual activities of Japanese geographers. The main emphases are put on problems of the articulation of traditional or indigenous Japanese geographical thought with modern academic geography, the roles played by the authors of geographical writings in the early Meiji period, the significance of the pioneers and outsiders of modern geography and characteristics of various schools of academic geography in Japan.
\end{abstract}

\section{General Remarks}

Recently in Japan, studies on geographical thought or the history of geographical thought have become flourishing, a fact in strong contrast to previous times when only a few specialists in the history of geography conducted research on very specific topics, or a limited number of geographers in specialized fields pursued historical reflections in the research pertaining to their specialized fields. In Japan, the recent surge of interest in the history of geographical thought began in the second half of the 1970s, in correspondence with the rise of interest in methodological and epistemological reflections on theoretical and quantitative geography and the emergence of new approaches such as the behavioural, phenomenological, radical-structural, and so on. Thus most of the recent studies in the history of geographical thought have been motivated by epistemological and methodological reflections that are presumably common to other countries. With regard to these trends, the Kyoto meeting of the Commission for the History of Geographical Thought of the International Geographical Union, held in 1980 , played a decisive role. In preparation for this meeting, in 1978, the Japanese Study Group for the History of Geographical Thought was formed with a grant-in-aid from the Japanese Ministry of Education, Science and Culture, and has since published three reports (Geographical Institute of Kyoto University 1980; TAKEUCHI, 1984d; Nozawa, 1985). This study group constitutes the nucleus of research activities in the history of geographical thought in Japan; and, on the initiative of the main members of the group, study groups for the history of geographical thought were created within the Association of Japanese Geographers in 1982, and a further study group having a similar purpose was formed in 1985 within the Human Geographical Society of Japan. One of the two authors of the present paper had advocated the necessity of studies in the history of geographical thought in Japan (TAKEUCHI, 1982) and, in 1984, on the occasion of the autumnal national convention of the Association of Japanese Geographers, both authors were responsible for the organization of a symposium having for its theme, 'Diffusion, Succession and Innovation in the History of Grographical Thought, Mainly in Japan' (TAKEuchi and NozAWA, 1985).

In recent studies on the history of geographical thought, the term 'geographical thought' is to be understood in a broad sense; it is not limited to the history of so-called academic geography, but

* Faculty of Social Studies, Hitotsubashi University, Kunitachi-shi, Tokyo, 186.

** Department of Geography, Faculty of Letters, Kyushu University, Fukuoka-shi, 812. 
includes geographical knowledge in general, as well as cosmological aspects and territorial consciousness, or the awareness of various societies, all of which have been and are expressed not only by means of the written word or academic jargon, but also by a diversity of other kinds of language -pictorial, cartographic, paysagère, and so on. A certain number of pioneering studies on the history of geographical thought, in this broader sense, already existed in Japan before World War II; early studies on the world image and a geographical knowledge of the world as found in ancient Chinese and Japanese maps and geographical books (Ogawa, 1928-29; Fujita, 1932; Ayuzawa, 1940) still maintain their scientific value, and many researchers continue the pursuit of studies in this field (UNNO, 1954, 1980, 1982, 1984a, 1984b; FunAKoshi, 1984, 1985). In present-day studies, however, there is an interest in the relativization of modern geographical science through the analyses of the system of knowledge that existed prior to the emergence of modern science or lore, and the system of the geographical knowledge of nonEuropean worlds-studies, that is, of the kind J.K. WRIGHT encouraged in the early 1940s.

According to Maruyama (1963), a scholar in the intellectual history of Japan, the mode of thought now under discussion consists of four strata or levels; the first of these comprises abstract and systematic theory and/or doctrine; the second, a comprehensive image of the world, nature and life; the third, opinions and attitudes related to concrete problems; and the fourth a perception of life and living that occurs prior to the process of reasoning. Hence, Maruyama points out the multifarious aspects of the meanings of thought and the necessity of analyzing the articulation between the above strata or levels of thought. He insists also that, while the upper strata are important in giving orientation to the thought, the energy supporting and promoting the thought is stronger in the lower strata. On the basis of the framework thus postulated by MARUYAMA, we can say that the currently prevalent strong interest in the geographical lore of the different societies that the study of the historical thought involves, represents the energy stimulating actual innovations in and reflections on geographical studies in Japan.

In the study of traditional Japanese geographi- cal thought, an important field of research is that of the study of pictorial maps, depicting ancient manors, mediaeval castle towns, pilgrimage itineraries and so on. But here we do not enter into a detailed review of this field of study, partly because a great deal of research in this field is conducted by historians rather than geographers. When a geographer takes it upon himself to carry out studies in this field, it is generally from the angle of historical interests; there are, though, a few exceptions such as the recent studies of YAMORI (1984a, 1984b) or IWAHANA (1985).

It is rather difficult to pinpoint the exact date of the establishment of academic geography in Japan, but most researchers define it as having occurred in the last years of the nineteenth century or the beginning of the twentieth, when chairs of geography were created at higher educational institutions such as higher normal schools and imperial universities. Prior to the establishment of academic geography, however, there existed a certain number of intellectuals who, after the opening of Japan to intercourse with foreign countries in the middle of the nineteenth century, published geographical writings under the influence of the newly accessible Western geography. They were not geographers in academia, but very often their works were utilized as geographical textbooks at schools or referred to by school teachers of geography. Moreover, they wrote these geographical works with the dual intention of propagating the ideology underlying Westernization and modernization on the one hand and nationalist sentiments on the other. From the period prior to the formation of academic geography in Japan, certain topics have emerged, which are currently objects of active study, i.e.: 1) Geographical thought and the social role of the above-mentioned forerunners of geographical thought, and the articulation or non-articulation of their thought with traditional or indigenous geographical thought; 2 ) the process of the institutionalization of geography, with regard to the fields of both education and research; and 3) the social and ideological background of various trends or schools after the establishment of academic or orthodox geography in Japan. Where the formation of modern academic geography in Japan is concerned, the impact of Western geography has been very strong and a large number of 
studies on the history of Western geography have been produced by Japanese geographers (though, in the present review, which focuses on studies on the history of Japanese geographical thought, we do not examine contributions of this kind), as well as writings on the outlining the development of modern geography in Japan (NoMA, 1976; TAKEUCHI, 1976, 1984a; Pinchemel, 1980). By no means, however, can we omit from our review a survey of studies on a number of prominent figures who exercised a strong influence on the formation of geographical schools in Japan and studies on, also, certain 'outsider' geographers, who either worked outside the institutionalized academies or were in a minority regarding their stance in geography at that time. The works of these people are now in the process of being reevaluated in the light of present-day epistemological and methodological considerations.

\section{Studies in Traditional Chinese and Japanese Geographical Thought}

Because traditional Japanese thought has, as with many aspects of Japanese culture, a close relationship with that of the Chinese, many studies have been made on traditional Chinese geographical thought since the ancient period. According to UnNo (1954, 1980, 1982), the typical ancient Chinese cosmology depicts the sky as round and the earth as rectangular in a metaphysical representation based on the I Ching or the Book of Changes (VII-V century, B.C.), and the principle of Yang and Ying. Thus, the idea of a rectangular earth surrounded by the ocean is not peculiar to the Western tradition. Furthermore, there existed in ancient China an image of the world divided into three concentric zones and consisting of four extremities, four deserts and four seas. The four extremities mark the limits of the world and the four seas comprise the concrete world, consisting of China and its surrounding areas; while the four deserts are the intermediate areas existing between the four extremities and the four seas. UNNo concluded that this world image or view represented the perceptual and behavioural space of the Chinese people.

This type of Chinese cosmology most certainly influenced the world view of the Japanese. UNNO goes on to point out that, on the one hand, under the influence of Buddhist cosmology, the mediaeval thought of their country as being a small one, situated on the periphery of the world; hence they termed it zokusan hendo. Hendo means 'periphery' and zokusan is a Buddhist term meaning 'very small, like scattered millet grains'. But, on the other hand, under the influence of Chinese cosmology, the world came to consist of Japan, China and India, and her people often considered Japan a 'great country' because she was the chosen homeland of the deity Dainichi Nyorai (Mahavairocana), according to the Shingon sect of Buddhism. After the sixteenth century, on the basis of a more objective knowledge of the world introduced by the Jesuit missionaries, an ethnocentric world view emerged, which emphasized the superior or excellent physical qualities of Japan. This view was later advocated by the Confucianists and classical scholars of the Tokugawa period (UnNo, 1984a, 1984b).

UnNo also examines the term chiri (geography), the ideograms for which appeared for the first time in the I Ching and, in that work, referred to the kind of geomancy governing the location of houses, graveyards, settlements and castles. Apart from the I Ching, however, the term chiri, or dihlii as it is pronounced by the Chinese was used in the sense of chorographical description that had nothing to do with geomancy. UnNo sees in these two terms a common or universal meaning consisting of the mode of the existence of the earth, or the logic of the earth, and it was in this sense that the Japanese Confucianists of the Tokugawa period considered chiri necessary knowledge for rulers (TsujitA, 1968, 1979). Besides this indigenous geographical thought conceived by the ruling classes, there existed a traditional or indigenous geographical thought professed to by agronomists and the peasant class who insisted on agricultural methods suitable to the environmental conditions of each place (ARIzono, 1986; NAITO, 1984).

Even under the seclusionist policy, knowledge of world geography found its way into Japan by way of shipwrecked people, for example, who happened to have been picked up by foreign ships and so reached foreign shores. Another way was through the maps and geographical books brought to Japan by the Dutch and the Chinese, who had some access to Japan in spite of the prevailing se- 
clusionist policies. Thus the world image visualized by Japanese intellectuals, especially scholars in Dutch studies, gradually came closer to that of the world image of Westerners. In fact, scholars in Dutch studies were comparatively well-versed in the knowledge of the geographical position, acreage, population distribution, soil conditions, climate and products of foreign countries. On the eve of the opening of the country, knowledge such as this was also required by the shogunate and fief governments (han) (TsujiTA, 1968) for the purpose of the defence of the country. From the beginning of the nineteenth century, the Japanese began to acquire their own geographical knowledge on the basis of Western cartography and geography (Funakoshi, 1984, 1985). This is testified to by the following evidence: 1) First, a governmentcompiled world map, the Shintei bankoku zenzu (1810), the quality of content and representation method which were of a world standard for that time; 2 ) the achievement consisting of the compilation of maps of the whole of Japan by Tadataka INo (1745-1818), based on precise measurements of the land where Japan was located, and its exact location on the earth in terms of modern cartography and 3) the exploration of Hokkaido and Sakhalin by Rinzo MaмтYA (1780-1844), the results of which were incorporated in the abovementioned Shintei bankoku zenzu. His accurate cartographic representation of Sakhalin was first ever achieved. It is also necessary to note the cartographic achievements of Kageyasu TAKAHASHI (1785-1829), who was engaged in the complilation of the Shinsen bankoku zenzu. The late Shintaro Ayuzawa $(1940,1948)$ studied these achievements from the viewpoint of the influence of Western geography and cartography in Tokugawa Japan; but recent studies by FuNAKOSHI emphasize the original achievements of the pioneer geographers and cartographers. There is no doubt, whatsoever that these achievements constitute the basis of modern geography in Japan but, as will be discussed later, whether succeeding generations of geographers rightly used the inheritance left them by their predecessors is open to question.

There is a new trend of studies which tries to discover in traditional Chinese and Japanese thought something essential for geography, but which is heterogeneous to rational or positivistic modern Western geography. This new trend is expressed in studies that aim at discovering traditional or indigenous geographical thought in the landscape of ancient Japan, and in popular legends and pictorical maps of mediaeval times. These basically comprise studies of the symbolism of place, but some researchers base their analyses on semiotics, in order to obtain a universal perspective. Examining the ancient Japanese landscape, SENDA $(1980 a, b)$ interprets its structure by means of the combination of three types of signs, that is, a square, a line and a point. Senda finds in the forms of ancient cities and villages some schematized patterns of the combination of these sign elements. From a semiotic analysis, SENDA furthermore proceeds to an interpretation of the meaning of the patterns of arrangement of the landscape elements. According to him, for instance, concentric patterns of spatial arrangements involve dichotomous structures of the sacred-profane, center-periphery, and so on. The grid pattern which predominated in ancient Chinese and Japanese settlements can also be interpreted in terms of the dichotomy of north-south and east-west axes (SENDA, 1984).

SENDA is clearly strongly influenced by linguistic semiotics, an interest which had previously been cultivated by Ichiro Suizu. Recently, Suzu has developed his analysis towards an examination of the correspondence between linguistic expression and the Japanese-style combination of the constituent elements of landscape. He finds that many Japanese terms, such as $m a,{ }^{1)}$ for example, cannot be represented in terms of Euclidean space and tries to analyse the quality of depth (shinso) in the traditional living space of the Japanese, bestowing upon it a topological expression (Suizu, 1978, 1983, 1984, 1987). Where the studies of old pictorial maps are concerned, a new trend is the attempt to discover, by analyzing them, the cosmology and a geographical knowledge of past periods. These studies thus represent the new interest in the indigenous and essentially geographical thought expressed by languages other than the conventional ones.

\section{Studies on Modern Geography Prior to the Formation of Academic Geography}

With regard to the development of modern geography in Japan, the early Meiji period is most 
important, due to the following four points, which are naturally interconnected (TAKEUCHI, 1974b, 1987a, 1987b): 1) Publications of geographical works relating to foreign countries, written by the so-called Meiji enlightenment intellectuals; 2) breakdown of the traditional type of geographical description for which the compilation of maps, statistics and other governmental reports came to be substituted; 3) emphasis on geography and history in the modern compulsory education system which started in 1872 , and which had a marked significance for the institutionalization of geography; and 4) the introduction on a greatly increased scale of western geography, both by leading Japanese intellectuals and by foreign teachers in Japan. The full-scale introduction of geographical studies of foreign schools was realized, however, only after the establishment of academic geography.

The problems concerning the formation and development of modern geography in Japan are, firstly, the articulation of traditional or indigenous Japanese (or more broadly speaking, East Asian) geography and, secondly, the relationship between academic geography and non-academic geography in the process of the development of modern geography in Japan.

Unlike the geographical descriptions of foreign countries that appeared in the late Tokugawa period, and which had for their aim the encouragement of an awareness of a need for the defence of the country, geographical descriptions of the so-called enlightenment writers of the early Meiji period aimed at diffusing among the people a knowledge of the situation of foreign countries, especially that of advanced Western countries, in order to convince them of the necessity of the modernization of Japan. After the abandonment of the seclusionist policy, the Shogunate and han governments several times despatched the young elite of the country abroad, in order to have them aquire knowledge of foreign countries. Some of these people, such as Yukichi Funuzawa (1834-1901) and Masao UchIDA (1842-1876) published books on foreign geography upon returning to Japan. Among the many published works of Fukuzawa, who was a very influential thinker of the Japan of the Meiji period, were numerous books on foreign countries, one of which was the Seiyo-jijo ('Conditions in the West') in 1866 and 1868, and another the Sekai kuni-zukushi ('World Geography') in 1869. The latter, which advocated the universality of the progress of humanity on the basis of evolutionist doctrines and the possibility of and the necessity for Japan's catching up with Western countries, was widely adopted as a school textbook after the establishment of the compulsory education system (TAKEUCHI, 1974b, 1987b). In 1870, the Yochi-shiryaku ('Short Description of the World') of UcHIDA, which contained interpretations that were more environmentalist in nature than the works of FukUzawa, was also extensively used as a school textbook. The geographical works of FuKuZAwa and UCHIDA played a somewhat ideological role, but the content, itself, of the works chiefly constituted the translation or paraphrasing of conventional Western geographical books. The examination of the original books of the authors of Meiji geographical writings constitutes one of the more interesting themes of study (Minamoto, 1985). As they did not generally refer to the original academic achievements of Western geographers, however, these works were not appreciated to any notable extent by later Japanese geographers. Nevertheless, the relationship of enlightenment thought to geography needs to be analyzed in further detail (KamozaWA, 1984).

In contrast to the Meiji enlightenment writers, who were at no time specialists in geography, a certain number of intellectuals of a younger generation who studied geography in a more specialized fashion, either by going abroad to do so, or by consulting the works of Western academic geographers, appeared in the middle of the Meiji period. Their geographical writings were neither fully appreciated nor accepted as an inheritance by academic geographers after the beginning of this century but, nonetheless, they were the forerunners of academic geography in Japan. Recently, we see an increasing interest in the works of these forerunners and a number of biographical and bibliographical studies on them have recently been published (Мinamoto, 1975, 1977, 1978, 1981, 1984, 1985).

In the year 1894, Kanzo Uchimura (1861-1930), influential Protestant thinker of the late Meiji and Taisho periods published the Chirigaku-ko ('Considerations on Geography'), which later became retitled Chijin-ron ('Discussions on the Earth and Man'). There are two important 
aspects for consideration in the study of the geography of UCHIMURA; first, his geographical work was strongly influenced by the works of A. GuYoT, which he studied while at Amherst College in Massachusetts for two years (NomA, 1980; Tsujita, 1977a) and, secondly, the relationship or the conflict of his Protestant faith with geographical thought (Yamana, 1963; Oda, 1977). Yamana concludes that UCHIMURA's geographical thinking is nearer to C. RITTER's teleological thinking than to GuYoT's environmentalism. According to ODA, the Christianity of Uchimura was marked by a somewhat nationalistic character and, in fact, in Chijin-ron, he found in the destination of Japan conditioned, as it were, by the geographical situation of the country, the realization of the Divine Providence (ODA, 1977).

Shigetaka SHIGA (1863-1927) is generally considered one of the active journalists who propounded the nationalist ideology during the middle and late Meiji period; but, at the same time, he professed himself to be a geographer (Мinamoto, 1984). He used the term kokusui (nationality), which literally stands for nationalism or ultranationalism, but which, in a much broader sense, can also be taken to mean national integrity or national identity. According to SHIGA, kokusui is the product of geographical conditions in Japan and is maintained as such by the Japanese nation itself. One of his main works, the Nihon fukeiron ('Japanese Landscapes') (1894), was a work of exploration into kokusui or, in other words, a eulogy on the beauties of the Japanese landscapes, which constitutes the basis of a sentimental attachment to one's native land, and of patriotism or nationalism (SATo, 1973). In this work, ShigA emphasizes, apart from the traditional and conventional aesthetic viewpoint, which holds in admiration the harmonious and serene combination of land, water and trees, the taste for the wild and austere beauty of steep mountains, especially that of volcanoes. Minamoto points out the influence of Darwinian natural history and Western alpinism on ShigA's aesthetic viewpoint. Discussion and debate on SHIGA's nationalism have also taken place from time to time. Many recent studies find a difference between SHIGA's thought in the early period and in the late period of his career. According to some authors, who found that SHIGA based his writings on geography only at the early period when he wrote the Nihon fukei-ron and Chirigaku kogi ('Lectures on Geography') (1889), (SATo, 1973), during the later years of his life, after his retirement from political activities, he became a more expressed advocate of imperialist invasion and expansionism (IwAI, 1960-61); but, according to other authors (for instance, Minamoto, 1984; TAKeUCHI, 1987a), the late years of Shiga saw the abandonment of his chauvinistic viewpoint and the adoption of a more international-oriented stance, stressing the importance of understanding the viewpoint of other nations and appreciating their sperior qualities, while at the same chiding the Japanese for their insular mentality. Anyhow, SHIGA is one of the most interesting figures of preacademic geography to be examined in further detail.

While Uchimura and SHIGa both received their higher education at the Sapporo Agricultural College and thus had a common agronomical disciplinary basis, Tsunesaburo MaKIGUCHI (1871-1944), who was greatly influenced by SHIGA, and is famous today as founder of the Soka Gakkai, the militant Buddhist sect, was a school teacher of geography who had received a diploma from the Sapporo Normal School. He was a selftaught geographer who published Jinsei Chirigaku ('Geography of Human Lives') (1903), under the suppervision of SHIGA. This was the first systematic and voluminous book of human geography in Japan, but it was long neglected, mainly because of the author's lack of higher education and relatively low social status. It is only recently that he has come to be appreciated as a pioneer of human geography in Japan (Kunimatsu, 1972-73, 1978; TAKEMOTO, 1983; TAKEUCHI, 1984c). In this book, MAKIGUCHI discussed a systematic knowledge of the relationship between the environment and human lives, expressing thus, an environmental viewpoint in geography; but in the third part of this work, he analyzes the distribution of human phenomena, taking into consideration primary socioeconomic conditions (Kunimatsu, 1978). It is worthy of note that he introduced the nomothetical, locational viewpoint of A. von THÜNEN to explain the distribution of different kinds of land utilization (Онј, 1982, 1983). It was not until thirty years later that von THÜNEN's theory was to reappear generally in books of geography.

The increasing interest in these pre-academic 
pioneer geographers in the studies of the history of geographical thought in Japan, reflects the new reconsiderations in and new reflections on the history of academic geography in Japan, which had all but ignored the works of the pioneers. Only SHIGA received some attention on the part of the first geographers at the imperial universities.

\section{Discussions on Academic Geography}

Even before the establishment of academic geography, i.e., the creation of chairs of geography, in the imperial universities, there existed, though peripherally, programmes of lectures and reports and other activities pertaining to geography in academic circles. One of the activities involved the Tokyo Geographical Society established in 1879 by geologists, meteorologists, and botanists of the Imperial University of Tokyo, together with other people prominent in society (including, for example, high-ranking civil servants, aristocrats, journalists, military men, and so on); the society also founded the Journal of Geography which is still being published to this day. The role of this society in the development of modern geography in Japan was examined in detail by the late Ryuziro IsIDA (1984). In the first issue of the Journal of Geography (1889), Bunjiro Кото (1856-1935) wrote a paper on the significance of geography. It was actually a paraphrase of the first and second chapters of the first part of F. Ratzel's Anthropogeographie (TAMURA, 1978), but it clearly showed that Кото was well-informed regarding the state of geography in Europe. He also serially published 'Lectures on Geography', which introduced the Ratzelian system of geography (IsIDA, 1971b). Secondly, it should be noted that lectures in geography took place in the course of history and geography of the Faculty of Letters (Bunka Daigaku) after around 1887 (Yoshida, 1982). Goro IshiBASHI (1877-1946) was appointed associate professor of geography when the first course of geography at university level in Japan was established at the Inperial University of Kyoto in 1907; he himself had studied at the Imperial University of Tokyo between 1898 and 1901, and had attended lectures in physical geography delivered by a German historian, RiEss, who based his talks on the geological works of A. GEIKIE, as well as historical geographical lecutures delivered by $\mathrm{K}$. TsuboI, who paraph- rased Ratzel. Hence, with all this behind him, it was perhaps not entirely by chance that ISHIBASHI later tried to construct his system of human geography on the basis of Ratzelian works.

It is generally agreed that the creation of the courses of geography at the Imperial University of Kyoto in 1907 and at the Imperial University of Tokyo in 1919 were epochmaking events in the process of the institutionalization of geography in Japan (NAKAGAWA, 1975). Strong influences were exercised by the two heads of these two newlycreated departments of geography, that is, Takuji OGawa (1870-1941) at Kyoto and Naomasa YamaSAKI (1870-1929) at Tokyo (TsujITA, 1977b, 1982). 1970 was the centenary of the birth of these two founder-geographers, and on that occasion in 1971, the Association of Japanese Geographers organized special lectures and published special issues of the Geographical Review of Japan. In one of these lectures, Tora YoshiKawa, whose mentors were disciples of YamasaKI, pointed out that the influence of YAMASAKI had been especially strong in the field of geomorphology, especially where tectonically active areas were concerned, based on his direct observation of the crustal movements on the occasion of big earthquakes; and that he thus greatly stimulated later studies in dynamic geomorphology in Japan (YosHIKAWA, 1971). In contrast to the Department of Geography of the University of Tokyo, which tends to be oriented towards physical geography, operating as it has within the frame of the Faculty of Science, the Department of Geography of the University of Kyoto, founded by OGawA, is human geographyoriented, and characterized by its special endeavours in the field of historical and settlement geography. This was partly because it was founded within the frame of the Faculty of Letters, but was also due to the influence of OGAWA with his strong affinity for the Chinese classics (Suzu, 1971a). The third head of this department at Imperial University of Kyoto, Saneshige Kомакі, established an original methodology of historical geography which involved the reconstruction and analysis of the past landscape of a certain temporal section in the 1930s (AsHIKAGA, 1982). This methodology was succeeded to by the late Kenjiro FUנIOKA (1914-1985), who subsequently formed many students in the Kyoto school (SENDA, 1982a). Recently, as mentioned above, geographers from 
this school have advanced their studies from the reconstruction of a past landscape to a semantic analysis of the structure of the past landscape, and are thus linking historical geographical studies with research in geographical thought. However, studies such as these had already been pioneered by OGawa in his writings on traditional Chinese cosmology and on the reconstruction of the geographical knowledge of the ancient Chinese, on the basis of an analysis of the Chinese classics, including literature (Suzu, 1971a).

Under the direction of OGAWA and YAMASAKI, two rather distinct schools of geography were thus formed, respectively, in Japan. In fact, on the initiative of OGAWA and YAMASAKI, two academic societies were established, the Chikyu Gakudan (Academic Circle of the Globe) at Kyoto in 1925, and the Association of Japanese Geographers in Tokyo in 1926, which began to publish The Earth (1924-1937) and the Geographical Review of Japan (1924- ), respectively (TAKeuchI, 1984a, Noma, 1976). In the 1930s, the geographical school of the University of Tokyo came to be characterized by landscape and quantitative studies (IsHIKawA, 1980) under the leadership of Taro Tsujimura (1890-1983), second head of the department. Besides this, at the Tokyo Bunrika University and the Tokyo Higher Normal School (which were, institutionally, closely connected and, later, together became Tokyo Kyoiku University and then the present University of Tsukuba), a newly formed Department of Geography became very active in studies in regional geography under the leadership of Keiji TANAKA (1885-1975) and Kanzo UCHIDA (1888-1969). TANAKA, who studied Davisian geography in the United States, tried to systematize studies in regional geography, establishing definitions for numerous concepts of regionality. TANAKA's attempts resulted in a great deal of similarity to the methodology of Lautensach's general regional geography, though the two geographers carried out their studies independently (TAMURA, 1984). Regarding the Japanese geography of the 1930s, considerations have recently been made on quantitative geographical studies, of which the works of I. Matsui, T. Murata and late S. Yoshimura are representative, and which were most certainly forerunners of post-World War II quantitative geography. It is, however, somewhat difficult to trace the continuity between prewar attempts at and the much more thriving postwar activities in the pursuit of quantitative studies (OKuno, 1980; IshiKawa, 1980, 1982).

Besides the increasing interest in the different schools of the then newly-formed academic geography, there is also a resurgence of interest in the works of non-academic geographers and nonorthodox or outsider geographers in academic circles. The significance of these non-academic and outsider geographers, after the establishment of academic geography in Japan, differed from that of the forerunner geographers of the Meiji period. Very often, the works of the non-academic and outsider geographers attained an extremely high level of scientific achievement. While they were strongly influenced by academic geographers, they, at the same time represented, as it were, a viewpoint that was critical of the academic geography of the time. Generally, the non-academic geographers were teachers working in the field of geographic education, and they exercised a strong intellectual influence in this field. Notable among them were Michitoshi Odauchi (1875-1954) and Katsue Misawa (1885-1937). There is no doubt that the growing interest in these non-academic geographers represents a methodological reflection that is now taking place with regard to conventional academic geography, and a protest against the attitudes of conventional academic geographers who for so many years have failed to carry out a proper evaluation and application of the works of the non-academicians.

ODAuchi was one of the first graduates of the course of history and geography of the Higher Normal School of Tokyo and worked mainly as a geography teacher at the Waseda middle school, though he also lectured at some private universities. He came under the strong intellectual influence of Inazo NitoBe, who had graduated from the Sapporo Agricultural College and advocated studies of local histories and local societies. NITOBE and Kunio Yanagita (1875-1962), who is considered the founder of the Japanese folklore school, established the Kyodo-kai (Society for Homeland Studies) in 1910. This society was joined by intellectuals in various disciplines, in order to conduct empirical studies in various corners of Japan and to collect material for Japanese folklore studies. ODAUCHI was an active member of this group, together with the above-mentioned MakigucH 
(TaKeUCHI, 1974b). One of OdauchI's major geographical works Teito to Kinko ('The Capital CityTokyo and Its Environs') (1918), was the first systematic study of settlement geography in Japan, based on field work (YAMADA, 1986). He was also an active advocate of an education based on homeland studies, and his activities have recently attracted the attention of not only geographers (Kimoto, 1977), but also pedagogists (YAMASAKI, 1984). Misawa was also a geography teacher, who taught at the Suwa Middle School in Nagano Prefecture, and among those persons who followed his original and impressive teaching, several later became scholars in earth sciences, including geography. He also conducted numerous field surveys in his homeland, which met with the approval of academic geographers, and always continued to emphasize the necessity of geographical education based on field observation in the homelands of the pupils, and the necessity of the development of

$\begin{array}{llllllllllllllll}1830 & 1840 & 1850 & 1860 & 1870 & 1880 & 1890 & 1900 & 1910 & 1920 & 1930 & 1940 & 1950 & 1960 & 1970 & 1980\end{array}$

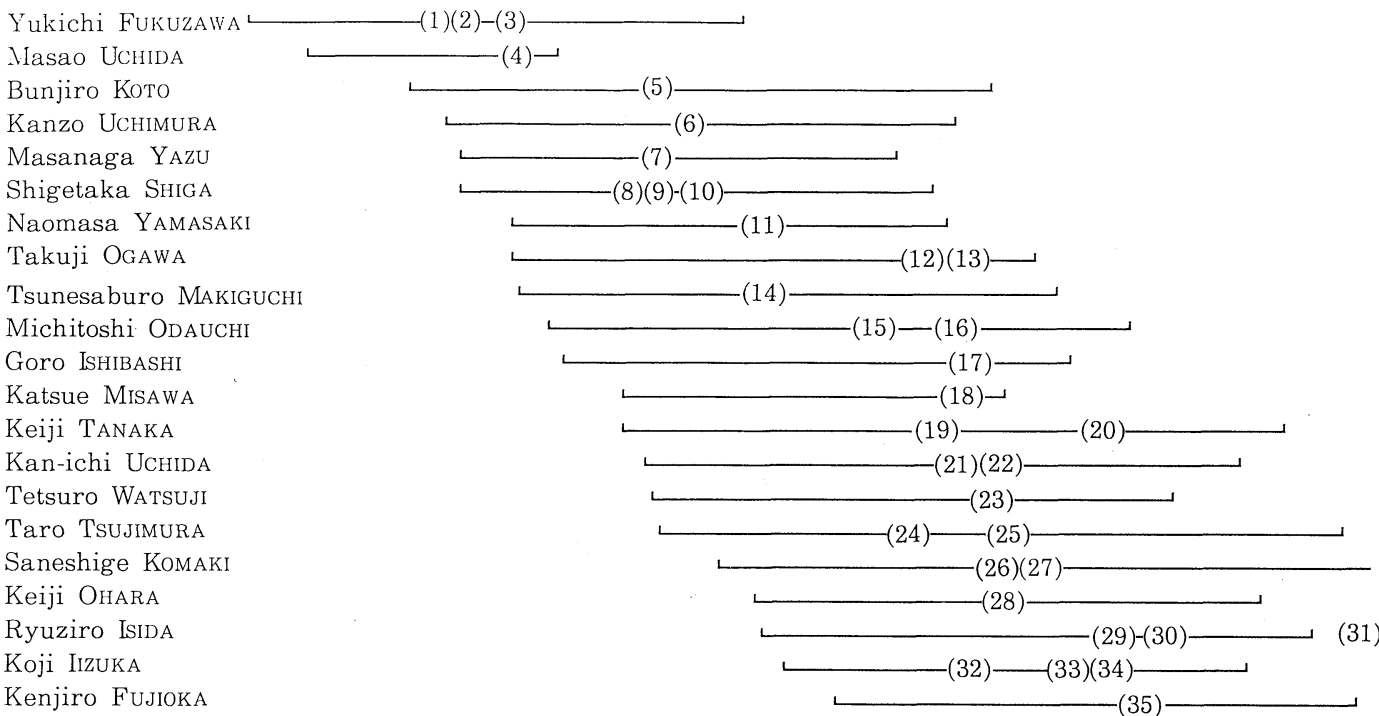

Figure 1. Date for lives and main works of persons mentioned

* Meiji Restoration in 1868

(1) Seiyo-jijo (Conditions in the West), 1866

(2) Sekai kuni-zukushi (World Geography), 1869

(3) Bunmei-ron no gairyaku (Outline of Civilization), 1875

(4) Yochi-shiryaku (Short Descriptions of the World), 1870-77

(5) Consideration on the Definition of Geography in the Occasion of the Publication of the "Journal of Geography" Journal of Geo graphy, 1889

(6) Chirigaku-ko (Considerations on Geography), 1894

(7) Nihon-chimongaku (Physiography of Japan), 1889

(8) Nanyo-jijo (Affairs in the Countries of the Southern Seas), 1887

(9) Chirigaku-kogi (Lectures in Geography), 1889

(10) Nihon-fukei-ron (Japanese Landscapes), 1894

(11) Dai-Nihon-chishi (Regional Geography of Greater Japan), Coauthor with Denzo $\mathrm{S}_{\text {ATO }}$, 1903-15

(12) Shina rekishi-chiri kenkyu (Historico-geographical Studies of China), 1928-29

(13) Jinbun-chirigaku kenkyu (Studies on Human Geography), 1928

(14) Jinsei chirigaku (Geography of Human Lives), 1903

(15) Teito to kinko (The Caoital City, Tokyo and Its Environs), 1918

(16) Kyodo-chiri kenkyu(Studies in Homeland Geography), 1930.

(17) On My Viewpoint of Geography, In Chiri-ronso (Collection of Geographical Papers), 1932

(18) Kyodo-chiri no mikata-chiiki-sei to sono ninshiki (Viewpoint of Homeland Geography-Understanding Regional Characteristics), 1931

(19) Tama Goryo-fukin no chishi (Geography of the Environs of the Tama Mausoleum), 1927
(20) Chirigaku no honshitsu to genri (The Nature and the Principles of Geography), 1949

(21) Kyodo chiri kenkyu (Studies on Homeland Geography), 1933

(22) Hatsu-shima no keizai-chiri nikansuru kenkyu (Studies of the Economic Geography of Hatsu Island), 1934

(23) Fudo (Climate), 1935

(24) Chikeigaku (Geomorphology), 1923

(25) Keikan-chirigaku kowa (Lectures on Landscape Geography), 1937

(26) Senshi-chirigaku kenkyu (Studies on Prehistorical Geography), 1937

(27) Nihon-chiseigaku sengen (Manifesto of Japanese Geopolitics), 1940

(28) Shakai-chirigaku no kiso-riron(Fundamental Theories of Social Geography), 1936

(29) Jinbun-chiri kenkyu-nyumon (Introduction to Human Geography), 1952

(30) Chirigaku no shakaika (Geography as a Social Science), 1958

(31) Nihon-niokeru kindai-chirigaku no seiritsu (Establishment of Modern Geography in Japan), 1984

(32) Shakai-chirigaku no doko (Trends of Social Geography), 1932

(33) Chirigaku-hihan-shakai-kagaku no tame no gakusetsu-shi-teki hansei-(Criticism of Geography-Historical Reflection for the Construction of Geography as a Discipline of the Social Sciences), 1947

(34) Jinmon-chirigakusetsu-shi-hoho-ron no tame no gakusetsu-shi-teki hansei-(Reflexion historique sur le progrès de la géographie humaine), 1949

(35) Sensi-chiiki oyobi toshi-iki no kenkyu (Studies of the Prehistorical Geography and Urban Geography), 1955 
locally based industries. Recently, three volumes of his works have been published, and his contributions to the development of Japanese geography are now coming in for reapplication (YAZAWA, 1979; Yoshino, 1970).

We should note here that the increased interest in local studies and the Japanese folklore movement before World War II were closely related to the miserable situation of the Japanese peasantry at that time. The movements were concerned, either directly or indirectly, with the improvement of the rural situation, which was one of extreme poverty. At the same time, however, this rural poverty constituted the social basis of the strengthening of Tennoist ultra-nationalism and chauvinistic expansionism. In this respect, the ideology underlining Odauchi's homeland studies, independently of his intentions, brought about the opening of the path to ultra-nationalism before World war II (TAKEUCHI, 1980b).

There are not many known studies on the ideological aspects of the geographical works of modern Japan, but one of those existing few is Ryuziro IsIDA's treatise on the history of the attempted compilation of the Kokokuchishi ('Regional Descriptions of the Japanese Empire') and the setback suffered by this attempt at complilation in the Meiji period. After the Meiji Restoration, the government instigated a project involving the systematic compilation of regional descriptions of the renewed Japanese empire, in order to collect the geographical data necessary for the administration of the newly-unified state, and also to demonstrate the prestige of the empire. But, because the intention was to compile the regional data according to the traditional Chinese and Japanese style of regional description, this work failed to answer the demands of the administration of the new state and was replaced by another compilation project, involving the publication of modern statistics and governmental cartographic surveys. The Kokokuchishi project was hence, abandoned with several volumes of drafts being all that remain of the initial project. IsiDA clearly analyzed the ideological background of this work of compilation and the reasons for the setbacks that prevented its final accomplishment (IsIDA, 1966). While it is true that the project of a nationwide systematic geographical description in the traditional style was discontinued in this way, on the other hand, compilation work involving local histories and regional geography, with the purpose of demonstrating the prestige of the administrative authorities, was inherited by local authorities. Publications of this kind are still being actively produced, but since the inception of the homeland improvement projects and the Japanese folklore movement, this kind of compilation work has found further support in the growing interest in local history and, after World War II, especially after the 1970's by the regionalist sentiments of the local people. The regionalist movement came to the fore in the 1970's with the spread of environmental deterioration and the enlarged regional disparity consequent upon the rapid growth of the national economy in the 1950s and 60s. At that time, however, there were few contributions from Japanese geographers, who were enclosed in a narrow disciplinary framework, or who spent most of their time indulging in sophisticated quantitative analyses.

Ryuziro ISIDA (1904-1979) was one of the examples of 'outsider' geographers operating inside the geographical academia, together with Koji IIzUKA (1907-1970). IsIDA consistently criticized the dominant current in academic geography, which tended to apply the viewpoint and methodology of the physical sciences to geography, and insisted that human geography was a social science. In the last year of his life, he dedicated himself to the study of the ideological and institutional background of the formation and development of modern geography in Japan, and a collection of his papers treating these particular issues was published posthumously (IsIDA, 1984). He paid little attention to the works of non-academic geographers, but his examination of the history of Japanese modern geography has greatly stimulated recent studies of the history of geographical thought in Japan (TAKEUCHI, 1983). IIZUKA was graduated from the Faculty of Economics, but immediately after graduation he shifted to geography and studied this subject at the University of Paris in the 1930s. He was active in introducing Vidalian geography in Japan, and vigorously criticized geographical environmentalism. Also, he strongly insisted that geography was a social science, though he did not carry out a critical examination of Vidalian geography (ОКАDA, 1975; TAKEUCHI, 1984b). Immediately after World War II, 
he strongly influenced the younger generation geographers of that time with his methodological writings based on studies he had carried out on the history of modern Western geography. $\mathrm{He}$ insisted that the study objective of geography was a territorially based social group; but he himself never engaged in empirical studies (Suzu, 1971b). Furthermore, he wielded considerable influence in the broader intellectual circles of postwar Japan, especially with regard to his criticism of the conventional Eurocentric stance of modern Japanese intellectuals, who tended to consider modernization synomymous with Westernization.

During the second half of the 1930's, and the first half of the 1940's the geopolitical movement gained currency, and a certain number of geographers were actively involved. Various currents were evident in Japanese geopolitic; some geopoliticians were under the strong influence of German geopolitics, partly because of the special connection of K. Haushofer with Japan. But others, especially Saneshige КомакI and his geographical school of Kyoto, insisted on an indigenous Japanese type of geopolitics, which was considered to have its roots in traditional Japanese thought. Nonetheless, all of them, irrespective of the particular current to which they belonged, turned the expansionism of militarist Japan during World War II to their own advantage. Because of this, their activities ceased with the defeat of Japan in the war, and Japanese geopolitics was banned, socially and institutionally (TAKEUCHI, 1974a, 1980a). Except for a few rare cases, a critical examination of Japanese geopolitics has not been made at a scientific level. Under the militarist wartime regime, only Keishi OHARA (1903-1972) and IIzUKA expressed in writing their criticism of German-style geopolitics (TAKEUCHI, 1986).

One other deplorable case of the indifference of most Japanese geographers is the issue concerning the traditional Japanese concept of fudo. Fudo literally means 'wind and earth', but as traditional regional description has always been referred to from ancient times as fudoki, that is, 'description of $f u d o$ ', the term has come to mean not simply the environment but all the attributes pertaining to the place or the land. In the $1930 \mathrm{~s}$, a philosopher, Tetsuro WatsujI (1889-1960), interpreted this traditional concept in philosophical and ethical terms. After World War II, numerous researchers in intellectual history and economics examined this concept as one of the key terms by which the characteristics of Japanese culture are explained (Ueno, 1972; Kовауashi, 1977). Japanese geographers, however, only superficially criticize these arguments on fudo, identifying it with simple environmental determinism, and do not seriously concern themselves with the subject. As the French geographer A. BERQUE has recently pointed out (BERQUE, 1978-79, 1986), this concept is extremely important in the examination of traditional Japanese geographical thought or the geographical dimensions of the Japanese mentality. As the above case demonstrates, many prospects yet remain to be explored in future studies regarding the history of geographical thought in Japan.

(Received January 6, 1988)

(Accepted February 22, 1988).

\section{Notes}

1) The Japanese term $m a$ ' is very difficult to translate into English. It means 'space' in both the abstract and concrete sense, but it can also mean 'pause' in the musical or conversational sense. Hence $m a$ has both a spatial and temporal meaning. (In fact, the Chinese ideogram for this term is used, in Japanese as well as Chinese, to represent the concept of time [jikan] and of space [kukan]. In these two terms the syllable kan in Japanese is another pronunciation of the same ideogram that stands for $m a$.) The lack of separation between space and time, or the equation of one with the other, as expressed by the term $m a$, has given rise to a conceptual difference in perception between the East and the West.

\section{References}

ARIZONO, S. (1986): Kinseinosho no chirigakuteki kenkyu (Geographical Study on the Agronomical Books of the Early Modern Period), Kokonshoin, Tokyo, 301 p.

AsHIKAGA, K. (1982): Saneshige KOMAKI and Historical Geography. In Geographical Istitute of Kyoto University (ed.) (1982), 201-216. (J)

AyuzAWA, S. (1940): Toyo chiri shiso-shi kenkyu (Studies in History of Geographical Thought in the East), Nihon Daigaku, Dai-san futsu-bu, 305 p. (Republished under the title of Chirigaku-shi no kenkyu (Study in the History of Geography), Ainichi Shoin, 1948. Hara shobo, 1980.

AyuzAWA, S. (1948): Sakoku jidai no sekai chirigaku (World Geography under the Seclusion Period of Japan), Ainichi Shoin, Tokyo, $363 \mathrm{p}$.

BERQUE, A. (1978-79): Escape et Société au Japon: La notion de Fudo, Mondes Asiatiques, 16, 289-309. 
BERQUe, A. (1986): Le sauvage et l'artifice, Les Japonais devant la nature, Gallimard, $314 \mathrm{p}$.

Committee of History of Japanese Earth Sciences, Tokyo; Geographical Society (1984) Late Professor T. OGAWA and the Geographical Institute of Kyoto University: A Round-table Conversation with Professor Saneshige KomaKI, Journal of Geography, 93, 168-181. (J)

FujITA, M. (1932): Nihon chirigaku-shi (History of Geography in Japan), Toko-shoin, Tokyo, 493 p.

FunAKoshi, A. (1984): A View of Japanese Geography in the Early 19th Century, In K. TAKEUCHI (ed.) (1984d), 55-66.

Funakoshi, A. (1985): A Fragment on Japanese Geography in the Early 19th Century. Annual Reports of Studies in Humanities and Social Sciences. 17, Nara Women's University. 51-88. (J)

Geographical Institute of Kyoto University (ed.) (1980): Geographical Languages in Different Times and Places: Japanese Contributions to the History of Geographical Thought, $130 \mathrm{p}$.

Geographical Institute of Kyoto University (ed.) (1982): Chiri no shiso (Geographical Thought), Chijin-shobo, Kyoto, 320 p.

Geographical Institute of Kyoto University (ed.) (1983): Kukan, keikan, imeji (Space, Landscapes and Images), Chijin-shobo, Kyoto, 249 p.

Hatano, N. (1979): History of Discussions on the Japanese Landscape (Part I). Musashi Daigaku Jinmon Gakkai Zasshi, 111, 1-13. (J)

HATTORI, N. (1977): Contemporary Significanece of Watsuji's Work Fudo (Climate). Kagoshima Daigaku, Hobun Gakubu Kiyoo (Section of Leterature), 13, 201-224. (J)

IızUKA, K. (1942-43): Fundamental Characters of Geopolitics (1), (2), (3). Keizaigaku Ronso, 12, 816-844. 13, 288-314, 486-496. The revised version of these papers later appeared in K. IIZUKA: Jinmon-chiri gakusetsushi-hoho-ron no tame no gakusetsu-shi-teki hansei (Réflexion historique sur le progrès de la géograprie humaiue Nihonhyoron-sha, 1949. (J-E)

IsHIKAWA, Y. (1980): Quantitative Studies in Japan in the Early Nineteen-thirties, In Geographical Institute of Kyoto University (ed.) (1980), 82-84.

ISHIKAWA, Y.(1982): A Research of Quantitative Studies in Japan in the Early Nineteen-thirties, In Geographical Institute of Kyoto University (ed.) 289-297. (J).

IsIDA, R. (1966): Chorographical Studies in Japan: Tradition and Its Background of Thought, Geographical Review of Japan, 39, 348-356. (J-E)

IsIDA, R. (1969): On the Publication of the Geographical Society of Tokyo (1878-1897): As Materials for the History of Japanese Geography in the First Half of the Meiji Period, Hitotsubashi University Research Series, Social Studies, 10, 1-83. (J)

IsIDA, R. (1971a): Trends of the Thought in Geography in Japan from the 1870's to the 1920's: A Personal View, Geographical Review of Japan, 44, 532-552. (J-E)

IsIDA, R. (1971b): From the Foundation of the Journal of
Geography (1889) to the Year of the Great Kanto Earthquake: Study on the History of Modern Japanese Geography, Hitotsubashi University Research Series, Social Studies, 11, 1-95. (J)

ISIDA, R. (1984): Nihon ni okeru kindai chirigaku no seiritsu (Establishment of Modern Geography in Japan), Taimeido, Tokyo, 310 p. This is a collection of his papers published after 1966.

IWAHANA, H. (1985): Spatial Cognition of Mount Takeyama Shugen in Sankei Mandala. The Historical Geographic Review, 27, 131-149. (J)

IWAI, T. (1960-61): On Shigetaka SHIGA, (1), (2), and (3). Ritsumeikan Bungaka, 186, 1309-1330. 194, 640-658, 198, 1003-1024. (J)

KamozaWA, I. (1985): Why Geographical Thoughts of Meiji Enlightenment Thinkers Were Not Inherited by Academicians. Nihon Chirigakkai Yokoshu, 26. (J)

Kimoto, T. (1977): Formation of the Ideas of ODAUCHI in Human Geography. The Bulletin of the Faculty of Humanities, Wako University, 14, 19-33. (J)

Kimoto, T. (1980): Michitoshi ODAuchi: His Life and Works. The Bulletin of the Faculty of Humanities, Wako University, 15. 19-25. (J)

Kobayashi, S. (1977): Environment, Personality of Peoples, and Geography-An Essay on the 'Fudoron' or Discussion Concerning the Relation between Environment and Personality of Peoples-. Annuals of the Japan Association of Economic Geography, 23(2), 31-44. (J-E)

Kunimatsu, H. (1972-73): Geography of MaKiguCHI and Modern Geography (1), (2). Senshu Daigaku Jinmon Ronshu, 10, 83-106; 11, 23-79. (J)

Kunimatsu, H. (1978): "Jinsei chirigaku” gairon (Treatise on 'Geography of Human Lives'), Daisan Bunmeisha, Tokyo, $268+$ vp.

Maruyama, M. (1963): On the Conception of Intellectual History: Its Types, Extents and Objects, In $\mathrm{K}$. TAKEDA (ed.): Shisoshi no hoho to taisho (Methods and Objectives of Studies of the Intellectual History). Sobunsha, 3-33. (J)

Minamoto, S. (1975): Shigetaka ShigA's Geographical Works-A Bibliographic Survey-(1). Library and Information Science, 13, 183-204. (J)

Minamoto, S. (1977): UchimURA Kanzo's Geographic Works-A Bibliographic Survey-(1). Memoirs of Shukutoku College, 11, 1-23. (J)

Minamoto, S. (1978): Masanaga YazU's Geographical Works-A Bibliographic Survey-(1). Memoirs of Shukutoku College, 13, 31-97. (J)

Minamoto, S. (1981): A Study on Nihon chimongaku (The Physiography of Japan) by Masanaga YAZU. Annals of the Tohoku Geographical Association, 33 (2), 89-99. (J-E)

Minamoto, S. (1984): Shigetaka Shiga 1863-1927, Geographers: Biobibliographical Studies, 8, 95-105.

Minamoto, S. (1985): A Study of J.M.D. Meiklejohn's A New Geography on the Comparative Method, Geographical Review of Japan, series B, 58, 195-207.

NAITo, M. (1984): From the Adaptation to the Transfor- 
mation of the Environment: Changing Concept of 'suido' (water and soil) Seen in Agronomical Books. Nihon Chirigakkai Yokoshu, 26. (J)

NAKAGAWA, K. (1975): History of Geography in Meiji Era: Specially in the 20's and 30's. The Human Geography, 27, 501-514. (J)

NisHIKAWA, O. (1979): A Note on Environmental Thought in the Time of the Tokugawa Shogunate. The Proceeding of the Department of Humanities, College of General Education, University of Tokyo, 69, 51-61. (J)

NomA, S. (1976): A History of Japanese Geography, In S. KIUCHI (ed.):Geography in Japan. University of Tokyo Press, 3-16.

NomA, S. (1980): Notes of UchIMURA's 'Earth and Man' in Relation with Guyot. Sokadaigaku Soritsu Jusshunen Ronbunshu, 758-766. (J)

NozAwa, H. (ed.) (1986): Cosmology, Epistemology and the History of Geography: Japanese Contributions to the History of Geographical Thought (3), Institute of Geography, Fuculty of Letters, Kyushu University, $82 \mathrm{p}$.

ODA, S. (1977): On 'Earth and Man' of Kanzo UchimurA. Kikan Nihon Shisoshi, 3, 117-134. (J)

OGAWA, T. (1928-29): Shina rekishi-chirigaku kenkyu, Sei, Zoku (Historico-geographical Studies of China, I, II), Kobundo-shobo, 404 p. and 610 p.

OHJI, T. (1982): Introduction in Japan of von Thunen's 'Isolated State': Its Presentation in Tsunesaburo Makiguchi's "Geography of Human Lives", In Geographical Institute of Kyoto University (ed.) (1982), 271-288. (J)

OHJI, T. (1983): The Acceptance Process of von Thunen's 'Isolated State' in Meiji Japan, In Geographical Institute of Kyoto University (1983), 7-35. (J)

OKADA, T. (1975): On the History of Geography Studied by Koji İzUKA, Geographical Sciences, 22, 16-24. (J-E)

OKADA, T. (1979): Koji IIzUKA's Participation in the National Affairs and His Studies before and during World War II 1931-1945. Geographical Review of Japan, 52, 233-250. (J-E)

OKADA, T. (1981): Koji İZUKA's Speech and Writing during the Early Years after World War II 1945-52. Geographical Sciences, 34, 32-36. 35, 24-33. (J-E)

OKADA, T. (1982): Koji IIzUKA's Treatises on Geography during the Early Years after World War II, In Committee for the Commemoration of the Retirement of Professor H. IsHIDA from the University of Hiroshima (ed.). Chiiki-sono bunka to shizen (The Region: Its Cultural and Phisical Aspects), 508-517. (J)

OKuno, T. (1980): The Fifty Years' Progress of Quantitative Geography. Recent Progress of Natural Sciences in Japan, 5, 131-140.

Pinchemel, P. (1980): L'histoire de la geographie japonaise. L'Espace geographique, 9, 165-171.

SATO, Y. (1973): A Consideration on an Ultra-nationalistic Geography Discussions of Shigetaka SHIGA. Shikan, 86/87, 71-85.

SEndA, M. (1979): The Structure of Ancient Space Studies in Geography. Studies in Geography, Nara
Women's University, 1, 40-58. (J-E)

SENDA, M. (1980a): A Semiotic Approach to Geographical Space. Human Geography, 32, 47-62. (J-E)

SENDA, M. (1980b): Expression of Geographical Space in Ancient Japan, In Geographical Institute of Kyoto University (ed.) (1980), 30-34.

SendA, M. (1982a): Progress in Japanese Historical Geography. Journal of Historical Geography, 8, 170-181.

SendA, M. (1982b): Perceived Space in Ancient Japan, In A.R.H. Baker and M. Billinge (eds.), Period and Place: Research Methods in Historical Geography, Cambridge University Press, Cambridge, 212-219.

SendA, M. (1984): Territorial Possession in Ancient Japan: The Real and the Perceived, In The Association of Japanese Geographers (ed.), Geography of Japan, Teikoku-shoin, Tokyo, 101-120.

SuIzU, I. (1971a): Takuji OGAWA and His Contribution to Historical Geography in Japan, Geographical Review of Japan, 44, 565-580. (J-E)

SuizU, I. (1971b): Late Prof. Koji IrzuKA and His Human Geography, Human Geography, 23, 619-645. (J-E)

Suizu, I. (1978): Geography and Topology. Human Geography, 30, 1-16. (J-E)

SuIZU, I. (1983): Codes of Landscape: The Geography of $m a$, In Geographical Institute of Kyoto University (ed.) (1983), 207-249.

Suizu, I. (1984): The Codes of Japanese Landscape: An Attempt at Topological Geography, Geographical Review of Japan, Series B, 57, 1-21. A modified version of this paper is included in K. TAKEUCHI (ed.) 1984d, 9-26.

SuIZU, I. (1987): Keikan no shinso (The Depth of Landscape), Chijin-shobo, Kyoto, $302 \mathrm{p}$.

TAкемото, S. (1983): A Study of the Reform Theories on School Geography from the End of Meiji Era to Taisho Era. In the Case of Tsunesaburo Makiguchi. Geographical Sciences, 38, 109-119. (J-E)

TAKEUCHI, K. (1974a): Geopolitics and Geography in Japan. Hitotsubashi Review, 72, 169-191. (J)

TAKEUCHI, K. (1974b): The Origins of Human Geography in Japan. Hitotsubashi Journal of Arts and Sciences, 15, 1-13.

TAKeuchi, K. (1976): General Remarks on Human Geography during the Past Fifty Years, In S. KIUCHI (ed.), Geography in Japan, University of Tokyo Press, 107-112.

TAKeuchi, K. (1980a): Geopolitics and Geography in Japan: Re-examined. Hitotsubashi Journal of Social Studies, 12, 14-24.

TAKEUCHI, K. (1980b): Some remarks on the History of Regional Description and the Tradition of Regionalism in Modern Japan. Progress in Human Geography, 4, 238-248.

TAKEUCHI, K. (1982): Tasks of the Study Group for the History of Geographical Thought of the Association of Japanese Geographers. Nihon Chirigakkai Yokoshu, 22. (J).

TAKeuchI, K. (1983): On One Person's Geography: The Case of the Late Professor Ryuziro Isida. Hitotsubashi 
Review, 89, 115-134. (J)

TAKEUCHI, K. (1984a): Japan, In R.J. JohNSTON and P. Claval (eds.), Geography Since the Second World War: An International Survey, Croom Helm, 235-265.

TAKEuchi, K. (1984b): Two Outsiders: An Aspect of Modern Academic Geography in Japan, In K. TAKEUCHI, (ed.) (1984d), 89-100.

TAKEUCHI, K. (1984c): Strategies of Heterodox Researchers in the National School of Geography and Their Roles in Shifting Paradigms in Geography. Paper Presented at the Meeting of the IGU Working Group on the History of Geographical Thought at Geneva in August 1984.

TAKEUCHI, K. (ed.) (1984d): Languages, Paradigms and Schools in Geography: Japanese Contributions to the History of Geographical Thought (2), Laboratory of Social Geography, Hitotsubashi University, Tokyo, $112 \mathrm{p}$.

TAKEUCHI, K. (1986): The Revival of Geopolitics and the New Trends in Political Geography, Hitotsubashi Review, 96, 523-546.

TAKEUCHI, K. (1987a): Paysage, language et nationalisme au Japon du Meiji. Contribution présentée au colloque international 'Les langages des représentation géographique', Venise-15 et 16 octobre 1987.

TAKEUCHI, K. (1987b): How Japan Learned about the Outside World: The Views of Other Countries Incorporated in Japanese School Textbooks, 1868-1986. Hitotsubashi Journal of Social Studies, 19, 1-13.

TaKeUCHI, K. and H. Nozawa (1985): Diffusion, Succession and Innovation in the History of Geographical Thought in Japan, Geographical Review of Japan, Series $A, \mathbf{5 8}, 103-112$.

TAMURA, M. (1978): Einführung der Deutschen Geographie von Bunjiro Kото in Japan-Die Herkunftsliteratur über die Definition der Geographie vom ihm anlässlich der Veröffertlichung des 'Journal of Geography', Geographical Review of Japan, 51, 406-415.

TAMURA, M. (1984): TANAKA Keiji to Nihon kindai chishigaku (Keiji Tanaka and Modern Regional Geography in Japan), Kokonshoin, Tokyo, 180 p.

TsujiTA, U. (1968): Geographical Thought in Early Modern Japan (1), (2). Nara Joshi Daigaku Bungakkai Kenkyu Nempo, 11, 1-29, 12, 25-56.

TsuJITA, U. (1969): Kinsei Nihon no chirigaku (Geography of Early Modern Japan), Taimeido, Tokyo, 325+12 p.

Tsujita, U. (1977a): Critical Survey Two Essays on Earth-Man Relation Written by A. GUYOT and K. UCHIMURA. Memoirs of the Nara University, 28-42, (J-E).

TsujiTA, U. (1977b): Naomasa Yamasaki 1870-1928, Geographers: Biobibliographical Studies, 1, 113-117.
Tsujita, U. (1982): Takuji Ogawa 1870-1941, Geographers: Biobibliographical Studies, 6, 71-76.

Ueno, N. (1972): Chishigaku no genten (Basis of Geography), Taimeido, Tokyo, $230 \mathrm{p}$.

UnNo, K. (1954): On the Geographical Conception of the Ancient Chinese People-with Special Reference to Their Spatial Concepts-Memoirs of Osaka Gakugei University, Series A, Culture and Social Sciences, 2, 115-134. (J)

UnNo, K. (1980): Geographical Thought of Chinese People. In Geographical institute of Kyoto University (ed.) (1980), 91-93.

UnNo, K. (1982): Geographical Concepts of Han People with Special Remarks on Their Geomantic View, In Geographical Institute of Kyoto University (ed.) (1982), 69-80.

UnNo, K. (1984a): The Medieval Japanese View of Their Country, In K. TAKEUCHI (ed.) (1984d), 37-43.

Unno, K. (1984b): The Japanese People's View of Their Country in the Early Modern Period. Nihon Chirigakkai Yokoshu, 26, (J)

YAMADA, M. (1986): Michitoshi ODAUCHI and Urban Geography. In SuIzu Ichiro sensei taikan kinenjigyo-kai (ed.), Jimmon-chirigaku no shiken (Perspectives on Human Geography), Taimeido, Tokyo, 87-97. (J).

YAMANA, S. (1963): Uchimura's 'Earth and Man' and Geography. Kagawa Daigaku Keizai Ronshu, 36, 171-185.

YAMASAKI, J. (1984): The Human Geography and Homeland Studies of Michitoshi Odauchi: Studies on the Educational Practices with Regard to Homeland Studies in the Early Years of Showa (1), Kyoiku-Hohoshi Kenkyu, 2, 77-99.

YAMORI, K. (1984a): The Difference between Maps and Landscapes: A Problem Concerning the History of Maps in Japan. TAKEUCHI (ed.) (1984d), 45-53.

YAMORI, K. (1984b): Kochizu to fukei (Old Maps and Landscapes), Chikuma-shobo, Tokyo, $343 \mathrm{p}$.

YazAWA, T. (ed.) (1979): Misawa Katsuei chosaku-shu (Collection of Works of Katsuei MISAWA), 3 vols., Misuzu-shobo, Tokyo.

YoshidA, T. (1982): The Vicissitudes in the Process of the Incorporation of Modern Human Geography in the History and Geography Courses of the Faculty of Letters, Imperial University of Tokyo. Geographical Institute of Kyoto University (ed.) (1982), 192-216. (J)

YoshiKaWA, T. (1971): Prof. N. YAMASAKI's Contribution to Tectonic Geomorphology. Geographical Review of Japan, 44, 552-564. (J-E)

Yoshino, M. (1970): Katsuei MisaWA (1855-1937), Bulletin of Faculty of Letters, Hosei University, 15, 1-24. (J) 


\section{日本における地理思想史研究の最近の動向 \\ 日本地理思想史を主にして}

\section{竹内 啓一* 野澤 秀樹**}

近年日本において「地理思想」あるいは「地理思想史」 の研究が隆盛をみている。ここでいう「地理思想(史)」 とはアカデミズムの世界における地理学に限らず，原 始・未開社会における地理的知識やコスモロジー, さら に空間認知の発達やテリトリー意識の形成についても含 まれる。すなわち「地理思想」とはアカデミズムのジャー ゴンによってしか表現されえない地理学の思想（学説, 方法など）に限られるものではなく，さまざまな社会集 団がそれぞれの場所において，言語に限らないあらゆる 種類の表現手段一絵画的なもの, 地図的なもの, 記号的 なもの，景観に表現された空間計画など一によって表現 された地理的知の認識にかかわるものである。

日本においてこのような「地理思想(史)」研究が盛ん になってきたのは1970年代末から80年代に入ってから で, 理論・計量地理学革命が与えた地理学方法論・認識 論への反省によって,「行動主義」、「現象学」,「ラディ カル」, あるいは「構造主義」などさまざまな立場の地 理学が主張されて来た時期に対応している。つまり理 論・計量地理学が拠って立った実証主義の認識論に対す る反省から，上述のような「地理思想」を探ることによ って, 近代地理学の認識方法に対する反省の系口を見出
そうとするものである。そのような反省は, 近代的な科 学としての地理学成立以前の地理的知の認識だけでな く, アカデミズム成立後における在野の地理学, あるい はアカデミズム内におけるアウトサイダーの地理学にも 目を向けさせることにもなる。

本稿では日本の地理学史研究において正統的な位置を しめ, かつ研究業績も多い欧米の地理学, 地理学者につ いての学説史的研究については触れない。従って, 本稿 では日本の地理思想, あるいは地理学思想を対象とした 近年の日本における研究成果について, 次の四つの研究 テーマに分けて, 研究動向を展望するものである。1)近 代以前の伝統的，あるいは土着（インド，中国を含む） の地理思想, 2)アカデミズム成立以前の, いわゆる明治 期の啓蒙思想家の地理思想, 3)广カデミズム地理学の成 立に関わった地理学者, およびアカデミズム成立後の, いわゆる在野の地理学者の地理思想, 4) 日本の近代地理 学の発達と社会的, イデオロギー的状況についての諸研 究である。なお, 伝統的地理思想の研究に大きな刺激を 与えている絵地図史の研究, 並びに民俗学的研究につい ては隣接諸科学と重なり研究成果が膨大になるため, ほ とんどふれることができなかった。
* 个186 国立市 一橋大学社会学部

** $\quad$ 个812 福岡市 九州大学文学部地理学教室 